\title{
Impact of the coronavirus pandemic in 2020 on the real estate market in Russia: legal aspects
}

\author{
Karine Avakyan ${ }^{1, *}$ and Gennady Pratsko ${ }^{1}$ \\ ${ }^{1}$ Don State Technical University, Gagarin sq., 1, Rostov on Don, 344003, Russia
}

\begin{abstract}
The purpose of the study: all spheres of society and economy have been exposed to the coronavirus infection and are forced to adapt to new conditions and rules. The state is taking various measures to support both society and business, and is introducing new regulations designed to reduce the negative consequences of the economic shutdown. The purpose of this work is to consider the consequences that the coronavirus pandemic has had on the real estate market, to research new technologies used by market participants, and also to analyze the most significant changes in federal legislation in Russia in the context of a pandemic.
\end{abstract}

\section{Introduction}

The economic situation associated with the spread of the COVID-19 virus has had a significant impact on all aspects of activities both in Russia and around the world, including the real estate market. At the present time, after the regime of self-isolation, the economy is gradually returning to normal activities: restrictions on the movement of the population, on doing business, the activities of participants in the real estate market, as well as the work of banks, MFC, realtors, developers, notaries, Rosreestr, etc. are removed. We can already talk about the impact and consequences of forced measures to restrict economic activity. In this article, the authors make an attempt to consider the short-term and long-term consequences on the real estate market, as well as transformation of the behavior model of market participants, new strategies and changes in the legal regulation of various transactions with real estate.

\section{Materials and methods}

In the context of the spread of COVID-19, the introduction of tough picture measures in connection with this and the suspension of economic activity in Europe, the USA, Asia, governments are actively supporting society and business, and are adopting various anti-crisis programs. One of the areas of such support is government support for the real estate market. The authors of these programs highlight the main areas of such support:

\footnotetext{
* Corresponding author: Mail8386@mail.ru
} 
support for citizens who purchase housing on a mortgage, and support for tenants and property owners of residential and commercial real estate. Ligita Gaspareniene Deimante Venclauskiene Rita Remeikiene [1] reviewed the various housing market models in transition economies [1], the impact of the COVID-19 pandemic on the housing market and the changes that took place - Harun Tanrıvermiş [2], the impact of the pandemic on bank lending was reviewed by Di Gonga Tao Jiangb Liping Luc [3-4], Maria Nicola Zaid Alsafi Catrin Sohrabi Ahmed Kerwan Ahmed Al-Jabir Christos Iosifidis Maliha Agha RiazAgha investigated the socio-economic consequences of the coronavirus pandemic [5] The influence of the pandemic on the development of the economy is emphasized in the works of S.M. Anpilov, A.N. Sorochaikin. (2020), S.S. Soldatova. (2020) [6-7].

At present, this problem has not been sufficiently studied, both theoretically and practically, because a crisis of this magnitude in the world economy occurs for the first time. Pandemics that occurred earlier in 2003 (SARS), 2009 (H1N1 09), but they were not of the same magnitude and, accordingly, not such economic consequences. Existing scientific papers on this issue consider the impact of the pandemic on markets from a regional perspective.

\section{Results}

At first glance, all economic activity has stopped, however, many experts note that the demand for housing purchases rose sharply before the introduction of self-isolation measures for the population, and many transactions were concluded in an emergency mode. The reason for this behavior was the fear of the danger of being infected in the process of searching for suitable properties and the introduction of quarantine, as well as the fall of the national currency during this period.

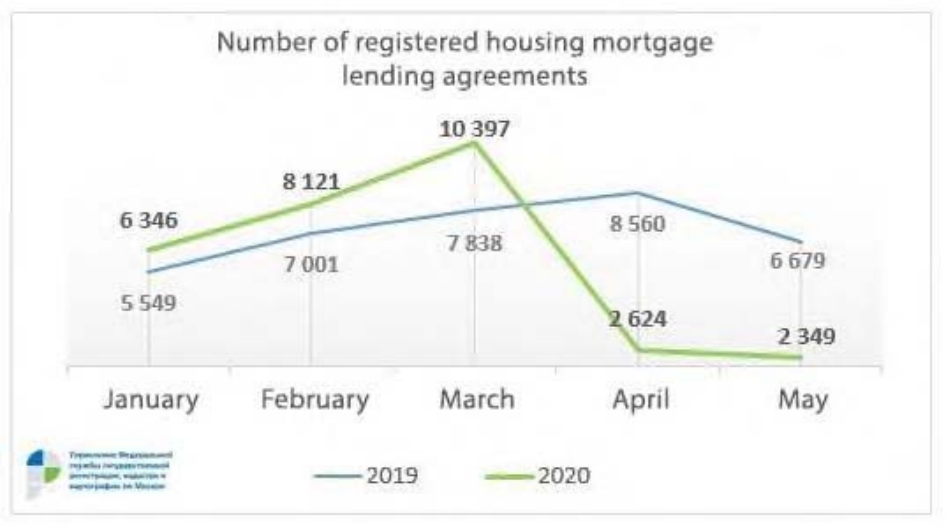

Fig. 1. Number of registered housing mortgage lending agreements [Rosreestr official website]

In April 2020, the number of transactions dropped sharply, primarily due to the fact that all government agencies and organizations related to the infrastructure of the real estate market suspended their activities. According to Rosreestr, the number of registered housing mortgage agreements in Moscow in 2020 in March is 10397, in April - 2624, and in May - 2349; contracts for participation in shared construction in March 6833, in April - 3845, in May - 3093. [Rosreestr official website: https://rosreestr.ru/site/press/news/v-moskve-na-chetvert-snizilos-chislo-sdelok-napervichnom-rynke-zhilya/; $\quad$ https://rosreestr.ru/site/press/news/chislozaregistrirovannykh-v-stolitse-ipotek-snizhaetsya-/, (application date: 18.06.2020)] This 
situation, according to realtors' estimates, continued for a month. In May, after the partial resumption of the activities of state structures, including online, transactions were mainly pre-agreed before the introduction of self-isolation, however, many buyers postponed transactions due to uncertainty with employment, earning their own income, problems with approval mortgage loans and financial market instability. For sellers, there was also an ambiguous situation, namely, the supply of objects decreased, but real estate prices have not changed yet, while consumer demand is limited. Similar crises occurred in Russia before: in 2008, in 2014, however, their nature was completely different. If in 2008 it was banking crisis, the consequence of the global banking crisis, in 2014 it was caused by international problems and sanctions against the Russian Federation. At present, the reasons for the crisis are different - almost all economies in the world have suspended business activity, the society is restricted in movement and work, which has led to a reduction in the income of both business and citizens. According to forecasts of the Institute "Development Center" Higher School of Economics, real incomes of the population in 2020 will decrease by $8.2 \%$ in the baseline scenario. [11] These factors have a significant impact on the real estate and mortgage market. In Russia, during the introduction of restrictive measures for the population and entrepreneurs in March 2020, there was an increase in unemployment (both latent and official: according to Rosstat, in April 2020 - 5.8\%, and in March 4.7\% [Rosstat official website: https://www.gks.ru/free_doc/2020/b20_01/100.htm, (application date: 18.06.2020)] and, as a result, an increase in loan delinquencies, toughening of bank requirements for borrowers, an increase in the down payment on mortgages and requirements for real estate.

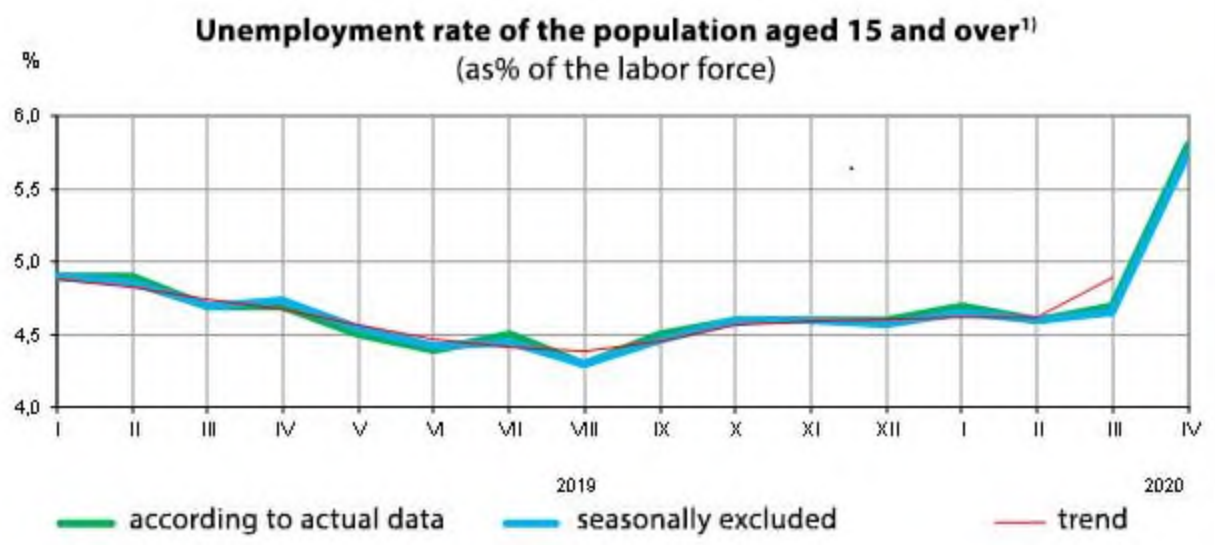

1) Evaluation of the data excluding the seasonal factor was carried out using the "JDemetra +"
program. Upon receipt of new data of statistical observations, the dynamics can be refined.

Fig. 2. Unemployment rate of the population aged 15 and over [Rosstat official website]

Practice shows that at present the down payment has grown from $10-15 \%$ to $20-50 \%$ of the cost of housing. The main requirement for borrowers is official employment and salary account with a bank. Banks give preference to employees of state and municipal bodies and organizations, banks see the most undesirable borrowers as young professionals, workers in tourism, restaurant business, trade in non-food products, household services, self-employed and individual entrepreneurs, etc. these categories and industries were most affected during the period of self-isolation. 
Significant changes have taken place in the legal regulation of the real estate market. During the period of self-isolation, the state took a number of measures aimed at reducing the negative impact of the crisis. These measures include an increase in payments to citizens who have lost their jobs, families with children, tax breaks for businesses, entrepreneurs and the self-employed, as well as some provisions related to the real estate market.

First of all, it is possible to single out changes in the norms of law governing the activity of real estate turnover, mortgage lending and state support for the construction and banking industries, and lease relations. The main changes concern both the procedure for repayment of existing loans and the conditions for issuing mortgage loans. The first changes are designed to support the mortgage market, primarily the banking sector, and prevent a sharp increase in defaults on loans issued. The latter are aimed at supporting the volume of mortgage loans and the construction of residential real estate.

Federal Law № 106-FZ of 03.04.2020 "On Amendments to the Federal Law" On the Central Bank of the Russian Federation (Bank of Russia) "and certain legislative acts of the Russian Federation regarding the specifics of changing the terms of a loan agreement a difficult life situation, a credit vacation for a period of up to 6 months, if the borrower's income has decreased by $30 \%$ compared to the average monthly income for the previous year. The deadline for applying for a credit vacation is no later than September 30, 2020. For this program, in accordance with the Decree of the Government of the Russian Federation of 03.04.2020 №435 "On establishing the maximum loan amount ...", the maximum amount of loans (loans) secured by a mortgage issued for purposes not related to entrepreneurship is not more than 2 million rubles; no more than 4.5 million rubles for housing located in Moscow; and no more than 3 million rubles for the Moscow region, St. Petersburg, the Far Eastern Federal District.

The procedure for granting credit holidays is as follows: the borrower is obliged to send a notification to the lender, either by the method specified in the agreement, or by means of radiotelephone communication known to the lender. The lender is obliged to make a decision within 5 days. During the credit holidays, no penalties (fines) are accrued, the lender has no right to make claims for early performance of credit obligations or collect on the collateral. The amount of the penalty and interest for using the loan is fixed on the day of the beginning of the grace period. Interest for the use of credit funds will be accrued during the grace period, but their payment has been postponed to the end of the credit holidays, and, consequently, the loan term will increase. The borrower has the right to terminate the grace period ahead of schedule, without penalties, by notifying the lender. Thus, these measures are designed to prevent a sharp increase in defaults on mortgages and other loans and borrowings, thereby supporting the banking sector.

In relation to the current loan agreements, the spread of infection in the territory of the Russian Federation and the establishment of a high alert regime can be attributed to force majeure circumstances. This is evidenced by the joint letter of the Ministry of Finance, the Ministry of Emergency Situations and the FAS dated 04/03/2020 № 24-0605 / 26578, 219-AG-70, ME / 28039/20 and the Review of the Presidium of the RF Armed Forces on certain issues of judicial practice related to the application legislation and measures to counter the spread of a new coronavirus infection (COVID-19) № 1 on the territory of the Russian Federation, approved on April 21, 2020. On the basis of these documents, the borrowers, in the event that it is possible to prove that these circumstances have influenced their financial situation, also have the right to send a notification to the bank about the impossibility of fulfilling obligations under loan 
agreements due to a force majeure circumstance under Art. 401 of the Civil Code of the Russian Federation for a certain period. In addition, the Bank of Russia also recommended not to accrue interest and fines under loan agreements, obligations under which are secured by a mortgage, and not to foreclose on the subject of a mortgage, if the borrower has a confirmed diagnosis of coronavirus infection and has informed the bank about these circumstances.

To support the volume of mortgage loans and the residential real estate construction market, the Government of the Russian Federation approved a mortgage lending program with a preferential interest rate of up to $6.5 \%$ per annum. According to the Decree of the Government of the Russian Federation of April 23, 2020 №566 "On approval of the Rules for reimbursing credit and other organizations for lost income on housing (mortgage) loans (loans) issued to citizens of the Russian Federation in 2020", the program applies to loans issued in the period from April 17 until November 1, 2020 for the acquisition by citizens of housing in newly built (put into operation) or under construction residential buildings under contracts of participation in shared construction and contracts of assignment of the right of claim under contracts of shared participation. Banks are obliged to issue loans to borrowers, while setting the interest rate on the loan no more than $6.5 \%$ per annum for the entire loan period. Such conditions can be used by citizens of the Russian Federation aged 21 to 65 years. In this case, the following conditions must be met:

- the loan amount does not exceed 3 million rubles for the regions of the Russian Federation; and 8 million rubles for the city of Moscow, the Moscow region, St. Petersburg and the Leningrad region;

- the amount of the borrower's own funds at least $20 \%$ of the price specified in the agreement for participation in shared construction (agreement of assignment of the right of claim), including with the use of maternity (family) capital funds, financial assistance from the budget of the constituent entities of the Russian Federation, local budgets, employers;

- repayment of the loan is carried out by annuity payments and the maximum loan term is up to 20 years.

The state undertakes to compensate the difference between the established interest rate $(6.5 \%$ per annum) and the bank's usual rate through an agent - DOM.RF JSC. The total amount of state support, that is, the amount of loans for which compensation will be made - up to 740 billion rubles for the entire period of the program.

Currently (June 2020), all banks have noted an increase in the number of applications for mortgages by 10 and $20 \%$, respectively, compared to April and May 2020 , primarily due to the state support program. During the period of this program since April 2020, more than 85 thousand applications have been accepted [13].

In addition, according to the Decree of the Government of the Russian Federation dated April 30, 2020 № 629 "On approval of the Rules for reimbursing credit institutions for lost income on loans issued for the implementation of housing construction projects" and Order of the Government of the Russian Federation dated April 30, 2020 № 1194-r in order to maintain construction The industry has allocated 12 billion rubles from the reserve Ford for monthly compensation of lost income by creditors in the amount of the difference between the interest rate established under the loan agreement and the key rate of the Bank of Russia on the day of compensation.

The operator of this program is also DOM.RF JSC. This program is valid until December 31, 2021 inclusive. The purpose of this program is to preserve jobs and support developers who carry out housing construction under contracts for participation in shared construction. The payment to banks of the difference between the interest rates established in the loan agreement with the developer for the provision of funds for the 
construction of apartment buildings is carried out by the decision of the Interdepartmental Commission, while the date of the loan agreement is no later than 05/01/2020.

The following requirements have been established for developers - the developer must not be in the process of reorganization, liquidation or bankruptcy, have debts in taxes and fees and loans, the number of employees remains at the same level, the developer has no problem objects, and he puts the objects into operation in accordance with the terms. Thus, adopting the above programs, the state provides significant financial support to the banking and construction industries.

One of the most important changes in the infrastructure of the real estate market are online transactions. In recent years, many legally significant actions have been transferred to remote mode. For example, over the past 5-7 years, banks have been underwriting loan applications online; from February 1, 2019, notaries are obliged to send applications and documents for state registration of rights on the basis of notarized contracts, as well as certificates of inheritance rights in relation to real estate; Rosreestr provides information on registered rights in electronic form through the FSIS USRN system, and also accepts applications in electronic form for state cadastral registration and state registration of rights and transactions signed with an enhanced qualified electronic signature. All this became possible thanks to the Federal Law "On Electronic Signatures" dated 06.04.2011 the Federal Law № 63 and the development of the State Service website and information portals of Rosreestr and the Cadastral Service and others. Currently, banks and developers are actively trying to implement the registration of transactions remotely in the complex, but it is impossible to completely transfer them online, because there are a number of operations that cannot be carried out without the presence of the parties (such as the issuance of an electronic digital signature, the departure of the real estate appraiser, etc.). Online transactions with real estate in the secondary market are used only partially for certain operations (obtaining information from Rosreestr, online underwriting of borrowers in the process of obtaining a mortgage loan, etc.).

The introduction of restrictive measures for business entailed a significant violation of the balance of rights and legitimate interests of business entities. Entrepreneurs, whose activities have been suspended and who rent premises and offices, as well as persons who rent out real estate, have found themselves in a difficult situation. The first - do not have the opportunity to conduct business, receive income and pay rent and utility bills, the second - without receiving income from rent payments, bear the burden of tax, rent and utility payments. In some cases, landlords are accommodating to tenants and reduce fees by $30-50 \%$ for the period of suspension of activities, however, many landlords are not ready to change the fees. In relation to them, the following novelties have been adopted in the legislative regulation of rental relations. The Federal Law of 01.04.2020 № 98 "On Amendments to Certain Legislative Acts of the Russian Federation on the Prevention and Elimination of Emergencies" established the obligation of the lessor, within 30 days from the date of the lessee's appeal, to conclude an additional agreement on deferring the payment of rent for 2020, while The tenant also has the right to demand a reduction in rent. If the tenant belongs to small or medium-sized businesses and works in the industries most affected by the coronavirus (the List approved by the Decree of the Government of the Russian Federation on April 3, 2020 № 434), they have the right to demand a reduction in rent for up to one year. If there is no agreement to reduce the rent or change the terms of the contract, the tenant has the right to withdraw from the contract unilaterally (no later than 01.10.2020), without paying penalties to the lessor (Article 450.1 of the Civil Code of the Russian Federation). The security deposit paid earlier to the lessor is not refundable. 
In relation to state and municipal property, a deferral of the rent for 2020 and the transfer of its payment in equal installments to 2021 , or in another way proposed by the tenant, is provided. Also, the tenant has the right to demand a reduction in rent.

These changes in legislation apply to business entities. These changes do not apply to contracts for the lease of residential premises, therefore, citizens must independently resolve disputes. The practice of resolving such disputes has not yet developed. As with commercial properties, it can be expected that the cost of renting residential premises will also decrease until all restrictions are lifted.

In conclusion, it can be noted that the coronavirus, has become an objective economic factor, had a significant impact on the whole world, and the economies of individual countries and Russia. The state allocated funds to support the construction and banking sectors of the economy, offsetting interest rates, thereby stimulating the demand for new buildings. Changes in the regulation of rental relations established by law are aimed at maintaining the parity of the legal rights and interests of all parties, however, they will entail a large number of legal disputes. Online registration of rights, virtual tours of objects and similar technologies will henceforth form the new digital infrastructure of the real estate market. But despite all the anti-crisis measures, taking into account the forecast of a decrease in real incomes of the population, activity in the real estate market in the coming years will decline.

\section{Metodology}

In connection with the introduction of tough picture measures in the countries of Europe, the USA, Asia, the states are adopting anti-crisis programs, allocating funds to support the economy. One of the directions is state support of the real estate market. The main directions of such support are highlighted: support for citizens purchasing housing on a mortgage, and support for citizens and entrepreneurs who rent real estate. Russia is also taking similar measures to mitigate the negative effects of the crisis.

\section{Results}

As a result of the work, the authors draw the following main conclusions: in connection with the pandemic and the measures taken by the state against the spread of infection, the real estate market has undergone major changes, both in the technologies used by market participants and from a legal point of view.

\section{References}

1. L. Gaspareniene, D. Venclauskiene, R. Remeikiene, Procedia - Social and Behavioral Sciences, Critical Review of Selected Housing Market Models Concerning the Factors that Make Influence on Housing Price Formation in the Countries with Transition Economy (The 2-dn International Scientific conference „Contemporary Issues in Business, Management and Education 2013“), 110, 419427 (2014)

2. H. Tanrıvermiş, Journal of Urban Management, Possible impacts of COVID-19 outbreak on real estate sector and possible changes to adopt: A situation analysis and general assessment on Turkish perspective, 9, Issue 3, 263-269 (2020) https://doi.org/10.1016/j.jum.2020.08.005 
3. Chi Wei Sua Xu Yu Caia Meng Qinb Ran Taoc, M. Umara, International Review of Economics \& Finance, Can bank credit withstand falling house price in China? https://doi.org/10.1016/j.iref.2020.09.013

4. Di Gonga Tao Jiangb Liping Luc, In Press, Corrected Proof What are Corrected Proof articles? Pandemic and bank lending: Evidence from the 2009 H1N1 pandemic https://doi.org/10.1016/j.frl.2020.101627

5. M. Nicola, Z. Alsafi, C. Sohrabi, A. Kerwan, A. Al-Jabir, C. Iosifidis, M. Agha, RiazAgha. International Journal of Surgery, The socio-economic implications of the coronavirus pandemic (COVID-19), $\mathbf{7 8 ,}$ 185-193 (2020) https://doi.org/10.1016/j.ijsu.2020.04.018

6. S. Sardar, I. Abdul-Khaliq, A. Ingar, H. Amaidia, N. Mansour, International Journal of Surgery, Available online 29, In Press, Journal Pre-proof, 'COVID-19 Lockdown: A protective measure or exacerbator of health inequalities? A comparison between the United Kingdom and India.' A commentary on "The socio-economic implications of the coronavirus and COVID-19 pandemic: A review" (2020) https://doi.org/10.1016/j.ijsu.2020.09.044

7. S. S. Soldatova, K. R. Pivkina, ECONOMIC IMPACT OF THE COVID-19 PANDEMIC FOR RUSSIA, student, 2, URL: https://cyberleninka.ru/article/n/ekonomicheskie-posledstviya-pandemii-covid-19dlya-rossii (Last accessed 19.06.2020)

8. S. M. Anpilov, A. N. Sorochaikin, RUSSIA IN THE POST-PANDEMIC WORLD, Fundamentals of EPM, 2(21) (2020) URL: https://cyberleninka.ru/article/n/rossiyav-postpandemiynom-mire (Last accessed 19.06.2020)

9. Scenario forecast of macroeconomic dynamics and household incomes until 2024 April 2020. Institute "Development Center", National Research University Higher School of Economics, URL: https://dcenter.hse.ru/data/2020/05/20/1548209626/DC\%20HSE\%20\%20forecast_macro_hh_income_2020_04.pdf (Last accessed 18.06.2020)

10. The increase in the number of applications for a mortgage is associated with the effect of the preferential program. URL: https://спроси.дом.pф/news/rost-chislaobrashhenij-za-ipotekoj-banki-svyazyvayut-s-dejstviem-lgotnoj-programmy/ (Last accessed 18.06.2020)

11. https://www.bundesfinanzministerium.de/Content/DE/Standardartikel/Themen/Schl aglichter/Konjunkturpaket/2020-06-03-konjunkturpaket-beschlossen.html (Last accessed 19.06.2020)

12. Federal Law № 106-FZ of 03.04.2020 "On Amendments to the Federal Law" On the Central Bank of the Russian Federation (Bank of Russia)" and certain legislative acts of the Russian Federation regarding the specifics of changing the terms of the loan agreement, loan agreement".

13. G. Barlevy, J. D. M. Fisher, Federal Reserve Bank of Chicago, Received 9 January 2020, Revised 26 August 2020, Available online 15 September 2020. Why were interest-only mortgages so popular during the U.S. housing boom? (2020) https://doi.org/10.1016/j.red.2020.09.001

14. A. Antoniades, C. W. Calomiris, European Journal of Political Economy, 101909, Mortgage market credit conditions and U.S. Presidential elections, 64, (2020) https://doi.org/10.1016/j.ejpoleco.2020.101909 
15. M. Brunetti, R. Ciciretti, Lj. Djordjevic, Till mortgage do us part: Mortgage switching costs and household's bank switching https://doi.org/10.1016/j.jbankfin.2020.105904

16. P. Bracke, C. A. L. Hilber, O. Silva, Journal of Urban Economics, Mortgage debt and entrepreneurship, 103, 52-66, (2018) https://doi.org/10.1016/j.jue.2017.10.003

17. J. Amankwah-Amoah, Z. Khan, G. Wood, European Management Journal, Available online 6 September 2020 COVID-19 and business failures: The paradoxes of experience, scale, and scope for theory and practice, In Press, Corrected ProofWhat are Corrected Proof articles? https://doi.org/10.1016/j.emj.2020 .09.002

18. M. Arcaya, Y. Nidam, A. Binet, R. Gibson, V. Gavin, Social Science \& Medicine, Available online 12 August 2020, 113290, In Press, Corrected Proof, What are Corrected Proof articles? https://doi.org/10.1016/j.socscimed.2020.113290Get rights and content

19. Naveen Donthu Anders Gustafsson, Journal of Business Research, 117, 284-289, (2020), Effects of COVID-19 on business and research, https://doi.org/10.1016/j.jbusres.2020.06.008

20. C. A. Tisdell, Economic Analysis and Policy, Economic, social and political issues raised by the COVID-19 pandemic, 68, 17-28 (2020) https://doi.org/10.1016/j.eap.2020.08.002

21. J. C. Palomino, J. G. Rodríguez, R. Sebastian, European Economic Review, 103564, Wage inequality and poverty effects of lockdown and social distancing in Europe, 129 (2020) https://doi.org/10.1016/j.euroecorev.2020.103564 